\title{
STRUCTURE MAP AND ISOPACH MAP OF THE INTERVAL BETWEEN THE B-GROOVE AND ORANGE MARKER OF THE GREEN RIVER FORMATION, NORTHERN PART OF THE PICEANCE CREEK BASIN, COLORADO
}

By John R. Dyni

These maps were prepared as part of a continuing study of the saline facies of the Eocene Green River Formation in the Piceance Creek basin in northwestern Colorado.

The structure map ( $1 .{ }^{-1}$ ) is drawn on the orange marker, a basinwide electric-log and stratigraphic marker in the lower part of the Green River Formation below the main body of oil shale containing the saline facies. The structure contours (interval $100 \mathrm{ft}$ ) are drawn on a geologic map by Donnel1 (1961, pl. 1). Partial electric and gamma ray-neutron logs of a typical drill hole near the depocenter of the Piceance Creek basin show the stratigraphic position of the orange and other important stratigraphic markers as well as the approximate vertical distribution of saline minerals. The "saline-rich" interval of rocks is shown on the logs. The saline-rich rocks consist of generally rich oil shale and contain halite and potential resources of dawsonite and nahcolite (Hite and Dyni, 1967).

Contours on the isopach map (interval $100 \mathrm{ft}$ ) show thicknesses of the sequence of rocks between the B-groove that marks the base of the Mahogany zone and the orange marker (p1. 2). The contour lines are drawn on a map published by Donneli (1961, p1. 1). The isopach map also shows the approximate area of halite deposition within the saline-rich zone, the thicknesses of dawsonite-bearing oil shale in selected drill holes as determined by Smith and Milton (1966), and the greatest areal extent of three persistent nahcolite units near the base of the saline-rich interval of rock.

\section{REFERENCES}

Donnell, J.R., 1961, Tertiary geology and oil-shale resources of the Piceance Creek basin between the Colorado and White Rivers, northwestern Colorado: U.S. Geol. Survey Bull. 1082-L, p. 835-891.

Hite, R. J., and Dyni, J. R., 1967, Potential resources of dawsonite and nahcolite in the Piceance Creek basin, northwest Colorado: Colorado School Mines Quart., v. 62, no. 3, p. 25-38.

Smith, J.W., and Milton, Charles, 1966, D.wwsonite in the Green River Formation of Colorado: Econ. Geology, v. 61, no. 6, p. 1029-1042.

This report is preliminary aed has not been edited or reviewed for conformity with U.S. Geological Survey standards 